\title{
DYNAMICS OF CARBON FOOTPRINT OF MAIZE PRODUCTION WITH DIFFERENT FUNCTIONAL UNITS IN SHANXI PROVINCE, CHINA
}

\author{
Jian-Fu Xue', Jian-Ying Qi', Zhi-Qiang Gao', , Ai-Xia Ren', Zhan-Biao Wang ${ }^{2}$ and \\ Tian-Qing Du ${ }^{1}$
}

\author{
${ }^{1}$ College of Agriculture, Shanxi Agricultural University, Jinzhong, Shanxi, 030801, China; ${ }^{2}$ Institute of Cotton \\ Research of the Chinese Academy of Agricultural Sciences, State Key Laboratory of Cotton Biology, Anyang, Henan \\ 455000, China \\ "Corresponding author's e-mail: gaosxau@163.com
}

\begin{abstract}
The reduction of greenhouse gases (GHGs) emissions from agricultural production is an efficient solution to mitigate global climate change. Maize (Zea mays L.) is most important grain crop in Shanxi Province, China. The environmental pressure due to large GHGs emissions associated with agricultural inputs during the process of maize production cannot be ignored. Based on the dataset from the National Cost-Benefit Survey for Agricultural Products, changes in carbon footprint (CF) with different functional units were assessed for maize production using life cycle assessment in Shanxi Province, China. The results showed that GHGs emissions sourced from maize production increased from $3633.7 \mathrm{~kg} \mathrm{CO}_{2}$-eq ha ${ }^{-1}$ in 2004 to $4043.3 \mathrm{~kg} \mathrm{CO}_{2}$-eq hain 2013 in Shanxi Province. Fertilizers application, soil $\mathrm{N}_{2} \mathrm{O}$ emission and irrigation contributed more than $85 \%$ of total GHGs emissions. Excluding soil organic carbon (SOC) storage, the CF of maize produced with different functional units (i.e., at yield-, production value-, cost-, net income-scale) showed a decreasing trend from 2004 to 2013. Taking SOC storage into account, the CF of maize with different functional units decreased by 38.3-44.7\% compared with that excluding SOC storage. In summary, reasonable fertilizer application and increasing SOC sequestration could be some potential solutions to reduce carbon footprint of maize production in Shanxi Province.
\end{abstract}

Keywords: Carbon footprint, maize, profit, Shanxi province, climate change.

\section{INTRODUCTION}

Global climate change has becoming a focus of attention for scientists, politicians and the public. Anthropogenic greenhouse gases (GHGs) emissions are crucial contributor to global climate change. How to reduce anthropogenic GHGs emissions effectively and mitigate global climate change are drawing the scientists' attention. Agricultural production is one of the major sources resulting in anthropogenic GHGs emissions. The reduction of GHGs emissions from agriculture production plays an important role in mitigating climate change through some effective measures. Quantitative evaluation of GHGs emissions associated with agricultural production is one of the most important parts to reduce global GHGs emissions. The carbon footprint (CF) is considered as a great indicator that could be used to quantitatively assess the impact of anthropogenic activities on climate change (Finkbeiner, 2009). According to International Standardization for Organization (ISO), a definition of CF for a specific product is the sum of GHGs emissions and removals in the whole product process expressed as $\mathrm{CO}_{2}$-eq based on a life cycle assessment using the single impact category of climate change (ISO, 2013).

Currently, there are many studies on the CF of agricultural products, however, differences in the $\mathrm{CF}$ and its components are observed due to different regions and diverse agricultural products in those studies (Dubey and Lal, 2009; Pathak et al., 2010). Meanwhile, researches on the CF of agricultural products have gradually increased in China (Cheng et al., 2015; Yan et al., 2015). The CF of agricultural products were assessed at area-scale and yield-scale in most current studies, however, little information on other functional units associated with economic perspectives (e.g., the cost, production value, and net income) was presented. The economic benefits from agricultural production could not only largely affect the farmers' willingness to work in agriculture, but also influence GHGs emissions. Therefore, the evaluation of the $\mathrm{CF}$ of agricultural products with different functional units is favor to learn the relationship between agricultural production and climate change from multiple perspectives.

The maize (Zea mays L.) is one of the three most important food staples in China and plays an essential role in food security and social stability. The maize accounts for $\sim 44.5 \%$ ( 1.7 million hectares, Mha) of the total sown area of grain crops and $\sim 68.5 \%$ ( $\sim 8.6$ million tons, Mt) of the total yield of grain crops in Shanxi Province in 2015 (NBSPRC, 2016). The GHGs emissions from maize production could not be neglected due to large amount of agricultural inputs (e.g., fertilizers, pesticides, diesel) in Shanxi Province. Therefore, 
the quantitative assessments of GHGs emissions and its components are important to develop low-carbon technologies for maize production in the region. Meanwhile, the cost of maize production gradually increases with the increase in agricultural inputs, while the maize planting can still earn more money for local farmers compared to other grain crops in Shanxi Province (NDRCPRC, 2005-2014). However, little information on the relationship between GHGs emissions and economic aspect is observed in the process of maize production. Consequently, the objectives of the study were: (i) to analyze the dynamic of GHGs emissions in the process of maize production during 2004 to 2013, (2) to assess the change in $\mathrm{CF}$ of maize production with different functional units (e.g., at yield-, production value-, cost-, net income-scale) in Shanxi Province.

\section{MATERIALS AND METHODS}

System boundary and functional units: In the study, the CF of maize production was assessed using life cycle assessment approach to provide the theoretical basis for the development of low-carbon agriculture in Shanxi Province. The study mainly analyzed hidden GHGs emissions from agricultural inputs (e.g., chemical fertilizers, diesel oil, pesticides and seeds), soil non- $\mathrm{CO}_{2}$ GHGs emissions and soil organic carbon (SOC) storage in the process of maize production in Shanxi province. The whole life cycle from raw material exploitation, production, and transportation of agricultural inputs to the farm gate (maize harvest) was defined as the system boundary of the study. The study included: (1) GHGs emissions from production, processing and transportation of agricultural inputs (e.g., fertilizers, seeds, pesticides); (2) energy consumption from farm machinery operations (e.g., tillage, sowing, harvesting, irrigation), and the energy consumption caused by the work of workers; (3) soil non- $\mathrm{CO}_{2}$ GHGs emissions (i.e., $\mathrm{CH}_{4}$ and $\mathrm{N}_{2} \mathrm{O}$ ). Generally, soil $\mathrm{CH}_{4}$ is not included into the $\mathrm{CF}$ calculation of crop product due to little $\mathrm{CH}_{4}$ emission even $\mathrm{CH}_{4}$ sink from the soil (Guo and Zhou, 2007), therefore, the CF calculation in the study only took soil $\mathrm{N}_{2} \mathrm{O}$ emission into account without $\mathrm{CH}_{4}$ emission. In addition, the $\mathrm{CF}$ of maize was assessed with different functional units at yield-, production value-, cost-, and net income-scale expressed as $\mathrm{kg} \mathrm{CO}_{2}$-eq $\mathrm{kg}^{-1}$, $\mathrm{kg} \mathrm{CO}_{2}$-eq $¥^{-1}$, $\mathrm{kg} \mathrm{CO}_{2}$-eq $¥^{-1}$, and $\mathrm{kg} \mathrm{CO}_{2}$-eq $¥^{-1}$, respectively.

Inventory data collection: The dataset of agricultural inputs and cost-benefit of maize production in Shanxi Province was mainly collected from the National Cost-Benefit Survey for Agricultural Products from 2004 to 2013 (NDRCPRC, 20052014). In the dataset, the total cost for maize production included the cost of all resources, consisting the cash, material object, labor and land. In current dataset, nitrogen fertilizer, phosphate fertilizer, potassium fertilizer and compound fertilizer were pure nutrient contents rather than actual use amount, however, the emission factor indicated the amount of GHGs emissions for per unit agricultural inputs. Therefore, the pure nutrient content of fertilizers was converted to actual use amount, and the conversion coefficient for urea, ammonium bicarbonate, calcium superphosphate, potassium chloride, and compound fertilizers were 46, 17, 17, 55 and $45 \%$, respectively.

Moreover, the energy consumption consisted mainly of diesel used for farm machinery operation in the process of maize production, including tillage, sowing, and harvest. The diesel consumption from farm machinery operation was estimated using total farm machinery operational expenses. The diesel amount was estimated by dividing the direct diesel cost by the price of diesel per kilogram $(\mathrm{kg})$ each year. According to Cui et al. (2011), the direct diesel cost for tillage, sowing, and harvest accounted for $\sim 13.9,5.4$ and $14.0 \%$ of total farm machinery operational expenses sourced from the National Cost-Benefit Survey for Agricultural Products. In addition, the energy consumption for irrigation sourced from China Rural Statistical Yearbook (NBSPRC, 2005-2014). Due to scarce information, the amounts of pesticides were referred from an investigation with $2.2 \mathrm{~kg} \mathrm{ha}^{-1}$ in Shanxi Province (Yan et al., 2015). The emission factors of GHGs for agricultural inputs in the study were shown in Table 1, and the inventories of GHGs emissions for maize production were shown in Table 2.

Table 1. Greenhouse gases emissions factors for different agricultural inputs in the study.

\begin{tabular}{|c|c|}
\hline Item & Emission factors \\
\hline Urea & $2.39 \mathrm{~kg} \mathrm{CO}_{2}-\mathrm{eq} \mathrm{kg}^{-1}$ \# \\
\hline Ammonium bicarbonate & $0.6484 \mathrm{~kg} \mathrm{CO}_{2}-\mathrm{eq} \mathrm{kg} \mathrm{kg}^{-1 \#}$ \\
\hline Others $\mathrm{N}$ fertilizers & $1.526 \mathrm{~kg} \mathrm{CO}_{2}-\mathrm{eq} \mathrm{kg}^{-1}$ \# \\
\hline Calcium superphosphates & $2.676 \mathrm{~kg} \mathrm{CO}_{2}-\mathrm{eq} \mathrm{kg}^{-1}$ \# \\
\hline Others $\mathrm{P}_{2} \mathrm{O}_{5}$ fertilizers & $1.631 \mathrm{~kg} \mathrm{CO}_{2}-\mathrm{eq} \mathrm{kg}^{-1}$ \# \\
\hline Potassium chloride & $0.7079 \mathrm{~kg} \mathrm{CO}_{2}-\mathrm{eq} \mathrm{kg}{ }^{-1 \#}$ \\
\hline Others $\mathrm{K}_{2} \mathrm{O}$ fertilizers & $0.6545 \mathrm{~kg} \mathrm{CO}_{2}$-eq kg ${ }^{-1 \#}$ \\
\hline Compound fertilizer & $1.772 \mathrm{~kg} \mathrm{CO}_{2}-\mathrm{eq} \mathrm{kg}^{-1}$ \# \\
\hline Diesel oil for machine & $4.9866 \mathrm{~kg} \mathrm{CO}_{2}-\mathrm{eq} \mathrm{kg}^{-1}$ \# \\
\hline Pesticides & $12.44 \mathrm{~kg} \mathrm{CO}_{2}$-eq kg ${ }^{-1 \#}$ \\
\hline Maize seed & $1.932 \mathrm{~kg} \mathrm{CO}_{2}$-eq kg $\mathrm{eg}^{-1 ~}$ \\
\hline Electricity for irrigation & $1.229 \mathrm{~kg} \mathrm{CO}_{2}-\mathrm{eq}(\mathrm{kW} \mathrm{h})^{-1 / \#}$ \\
\hline Labor & $0.86 \mathrm{~kg} \mathrm{CO}_{2}$-eq (person day) $)^{-1} \$$ \\
\hline \multicolumn{2}{|c|}{$\begin{array}{l}\text { \# The datasets of those emission factors for above agricultural input } \\
\text { sourced from the IKE eBalance v3.0 (IKE Environmenta } \\
\text { Technology CO., Ltd, China). }{ }^{\$} \text { The emission factor for labor sourced } \\
\text { from Liu et al. (2013) }\end{array}$} \\
\hline
\end{tabular}

Carbon footprint calculation: The CF of maize was determined through dividing all GHGs emissions from agricultural inputs and soil $\mathrm{N}_{2} \mathrm{O}$ emission in the process of maize production. The $\mathrm{CF}$ was calculated by the following Equation (1) and (2) (Gan et al., 2012; ISO 2013): 
Dynamics of carbon footprint of maize

Table 2. The inventory of greenhouse gases emissions from agricultural inputs in the process of maize production in Shanxi province.

\begin{tabular}{|c|c|c|c|c|c|c|c|c|c|c|}
\hline $\begin{array}{l}\text { Inputs } \\
\end{array}$ & 2004 & 2005 & 2006 & 2007 & 2008 & 2009 & 2010 & 2011 & 2012 & 2013 \\
\hline \multicolumn{11}{|c|}{${\text { Mechanical operation }{ }^{\dagger}\left(\mathrm{kg} \mathrm{ha}^{-1}\right)}$} \\
\hline Tillage & 12.43 & 12.57 & 12.26 & 13.92 & 14.59 & 14.56 & 14.41 & 15.25 & 18.80 & 21.85 \\
\hline Sowing & 4.80 & 4.85 & 4.73 & 5.37 & 5.63 & 5.62 & 5.56 & 5.89 & 7.26 & 8.43 \\
\hline Harvest & 12.46 & 12.60 & 12.29 & 13.95 & 14.63 & 14.59 & 14.45 & 15.29 & 18.85 & 21.90 \\
\hline \multicolumn{11}{|l|}{$\mathrm{N}$ fertilizers ${ }^{\dagger}\left(\mathrm{kg} \mathrm{ha}^{-1}\right)$} \\
\hline Urea & 155.9 & 155.5 & 154.6 & 168.6 & 223.4 & 229.2 & 216.8 & 211.0 & 216.2 & 212.0 \\
\hline Ammonium bicarbonate & 394.2 & 481.7 & 428.3 & 336.7 & 343.3 & 255.0 & 251.7 & 206.7 & 95.8 & 50.0 \\
\hline Others & - & - & 10.8 & 2.5 & 1.7 & - & - & - & - & - \\
\hline \multicolumn{11}{|l|}{ P fertilizers ${ }^{\dagger}\left(\mathrm{kg} \mathrm{ha}^{-1}\right)$} \\
\hline Calcium superphosphates & 263.8 & 322.9 & 338.8 & 299.1 & 298.2 & 255.9 & 250.6 & 186.2 & 92.6 & 45.9 \\
\hline Others & 7.1 & 15.9 & 37.9 & 4.4 & 16.8 & 28.2 & 1.8 & 28.2 & - & - \\
\hline \multicolumn{11}{|l|}{$\mathrm{K}_{\text {fertilizers }}{ }^{\dagger}\left(\mathrm{kg} \mathrm{ha}^{-1}\right)$} \\
\hline Potassium chloride & - & - & 0.8 & 2.7 & - & - & - & - & - & - \\
\hline Others & 1.6 & 14.7 & 18.3 & 0.8 & - & 0.5 & - & - & - & - \\
\hline \multicolumn{11}{|c|}{ Compound and mixed fertilizers ${ }^{\dagger}\left(\mathrm{kg} \mathrm{ha}^{-1}\right)$} \\
\hline Compound fertilizers & 182.7 & 120.7 & 142.7 & 205.3 & 168.0 & 190.0 & 238.0 & 304.7 & 359.7 & 499.7 \\
\hline Others & 22.3 & 9.7 & 34.3 & - & 7.3 & - & - & - & 19.0 & 9.0 \\
\hline Seed $^{\dagger}\left(\mathrm{kg} \mathrm{ha}^{-1}\right)$ & 40.8 & 39.8 & 38.6 & 40.4 & 35.9 & 34.4 & 30.3 & 29.1 & 24.9 & 25.4 \\
\hline Pesticides $\$\left(\mathrm{~kg} \mathrm{ha}^{-1}\right)$ & 2.2 & 2.2 & 2.2 & 2.2 & 2.2 & 2.2 & 2.2 & 2.2 & 2.2 & 2.2 \\
\hline Irrigation ${ }^{*}\left(\mathrm{~kW} \mathrm{~h} \mathrm{ha}^{-1}\right)$ & 356.8 & 466.2 & 505.4 & 566.5 & 692.3 & 767.0 & 576.3 & 630.0 & 1043.7 & 700.1 \\
\hline $\operatorname{Labor}^{\dagger}\left(\right.$ day ha $\left.^{-1}\right)$ & 156.3 & 147.5 & 141.0 & 134.7 & 143.3 & 136.4 & 136.7 & 135.3 & 119.6 & 116.6 \\
\hline $\operatorname{Film}^{\dagger}\left(\mathrm{kg} \mathrm{ha}^{-1}\right)$ & 3.8 & 3.6 & 3.5 & 5.1 & 3.3 & 3.3 & 5.0 & 5.6 & 7.2 & 7.5 \\
\hline
\end{tabular}

$$
C F=\frac{C E_{\text {total }}}{Y_{\text {maize }}}
$$

Where, $C F$ is the $\mathrm{CF}$ of maize with four functional units at yield- $\left(\mathrm{kg} \mathrm{CO}_{2}\right.$-eq kg ${ }^{-1}$ year $\left.{ }^{-1}\right)$, production value- $\left(\mathrm{kg} \mathrm{CO}_{2}\right.$-eq $¥^{-1}$ year $\left.{ }^{-1}\right)$, cost- $\left(\mathrm{kg} \mathrm{CO}_{2}\right.$-eq $¥^{-1}$ year $\left.{ }^{-1}\right)$, and net income-scale ( $\mathrm{kg} \mathrm{CO}_{2}$-eq $¥^{-1}$ year ${ }^{-1}$ ), respectively. $C E_{\text {total }}$ is the total GHGs emissions in the process of maize production $\left(\mathrm{kg} \mathrm{CO}_{2}\right.$-eq ha ${ }^{-1}$ year $\left.^{-1}\right)$, which was calculated by Equation (2); $Y_{\text {maize }}$ is the maize yield $\left(\mathrm{kg} \mathrm{ha}^{-1}\right.$ year $\left.^{-1}\right)$, production value $\left(¥ \mathrm{ha}^{-1}\right.$ year $\left.^{-1}\right)$, cost $\left(¥\right.$ ha $^{-1}$ year $\left.^{-1}\right)$, and net income $\left(¥ \mathrm{ha}^{-1}\right.$ year $\left.^{-1}\right)$, respectively.

$$
\begin{gathered}
C E_{\text {total }}=C E_{\text {inputs }}+C E_{\mathrm{N}_{2} \mathrm{O}} \\
C E_{\text {inpus }}=\sum_{i}\left(Q_{\text {used }} \times \varepsilon_{i}\right)
\end{gathered}
$$

Where, $C E_{\text {inputs }}$ is total amount of hidden GHGs emissions associated with agricultural inputs $\left(\mathrm{kg} \mathrm{CO}_{2}\right.$-eq ha ${ }^{-1}$ year $\left.^{-1}\right)$ for maize production; $C E_{\mathrm{N}_{2} \mathrm{O}}$ is the cumulative amount of direct and indirect soil $\mathrm{N}_{2} \mathrm{O}$ emissions due to $\mathrm{N}$ fertilizer application $\left(\mathrm{kg} \mathrm{CO}_{2}\right.$-eq ha ${ }^{-1}$ year $\left.^{-1}\right) ; Q_{\text {usedi }}$ is the amount of a $i$ th individual agricultural input applied in maize production process $\left(\mathrm{kg} \mathrm{ha}^{-1}\right.$ year $^{-1}$ ), including fertilizers, pesticides, seed, electrical energy for irrigation, and diesel for farm machinery operation; $\delta_{i}$ is the emission factor of individual agricultural input $\left(\mathrm{kg} \mathrm{CO}_{2}-\right.$ eq $\left.\mathrm{kg}^{-1}\right)$.

Moreover, soil $\mathrm{N}_{2} \mathrm{O}$ emission was estimated using the 2006 IPCC Guidelines for National Greenhouse Gas Inventories (IPCC, 2006). Nitrogen fertilizer use contributed mainly to direct and indirect emissions of soil $\mathrm{N}_{2} \mathrm{O}$ in the process of maize production, which was calculated by equation (4).

$$
C E_{\mathrm{N}_{2} \mathrm{O}}=D C E_{\mathrm{N}_{2} \mathrm{O}}+V C E_{\mathrm{N}_{2} \mathrm{O}}+L C E_{\mathrm{N}_{2} \mathrm{O}}
$$

Where, $D C E_{\mathrm{N}_{2} \mathrm{O}}$ is the direct $\mathrm{N}_{2} \mathrm{O}$ emission $\left(\mathrm{kg} \mathrm{CO}_{2}\right.$-eq ha ${ }^{-1}$ year ${ }^{-1}$ ); $V C E_{\mathrm{N}_{2} \mathrm{O}}$ is the amount of indirect $\mathrm{N}_{2} \mathrm{O}$ produced from atmospheric deposition of $\mathrm{N}$ volatilized as $\mathrm{NH}_{3}$ and $\mathrm{NO}_{\mathrm{x}}$ from farmland $\left(\mathrm{kg} \mathrm{CO}_{2}\right.$-eq ha ${ }^{-1}$ year $\left.^{-1}\right) ; L C E_{\mathrm{N}_{2} \mathrm{O}}$ is the amount of $\mathrm{N}_{2} \mathrm{O}$ produced from $\mathrm{N}$ leaching and runoff $(\mathrm{kg}$ $\mathrm{CO}_{2}$-eq ha ${ }^{-1}$ year ${ }^{-1}$ ). Above $\mathrm{N}_{2} \mathrm{O}$ emissions were calculated using the default value from 2006 IPCC Guidelines for National Greenhouse Gas Inventories (IPCC, 2006).

Farm management practices (e.g., soil tillage, fertilization, straw returned) could affect the SOC concentration and its distribution, then influencing SOC storage. Recently, some studies had taken SOC storage into account for calculating the CF of agricultural product (Gan et al., 2012; Xue et al., 2014). 


$$
C F_{\text {soc }}=\frac{C E_{\text {total }}-\Delta \mathrm{SOC}}{M}
$$

Where, $C F_{s o c}$ is the $\mathrm{CF}$ of maize production including the change in SOC storage. $\triangle S O C$ is the annual change in SOC storage $\left(\mathrm{kg} \mathrm{CO}_{2}\right.$-eq ha $\left.{ }^{-1} \mathrm{year}^{-1}\right)$, an estimated increase rate of $1624.3 \mathrm{~kg} \mathrm{CO}_{2}$-eq ha ${ }^{-1}$ year $^{-1}$ for SOC storage was used to calculate the CF of maize in Shanxi Province (Lu et al., 2009).

\section{RESULTS}

Change in greenhouse gases emissions of maize production: The GHGs emissions from maize production showed an increasing trend in the past decade in Shanxi Province (Table 3), ranging from $3633.7 \mathrm{~kg} \mathrm{CO}_{2}$-eq ha ${ }^{-1}$ in 2004 to $4043.3 \mathrm{~kg} \mathrm{CO}_{2}$-eq ha ${ }^{-1}$ in 2013. Fertilizers application, soil $\mathrm{N}_{2} \mathrm{O}$, and irrigation were major sources of GHGs emissions in the process of maize production, accounting for 35.9-49.5, 27.5-30.7 and $9.0-23.0 \%$ of the total GHGs emissions, respectively. The GHGs emissions associated with fertilizers application was mainly caused by nitrogen fertilizer and compound fertilizer use. However, the GHGs emissions from nitrogen fertilizer use showed a decreasing tread from 2008 to 2013, which from compound fertilizer it showed an increasing tread year by year with an increment of $53.8 \mathrm{~kg}$ $\mathrm{CO}_{2}$-eq ha $^{-1}$ year ${ }^{-1}$. Meanwhile, the GHGs emissions caused by phosphorus fertilizer use gradually decreased from 2004 to 2013 , with a decrement of $60.2 \mathrm{~kg} \mathrm{CO}_{2}$-eq ha-1 year-1. It is clearly that the reduction of GHGs emissions due to phosphate fertilizer and nitrogen fertilizer use was offset by the increase in that from compound fertilizer use. The GHGs emissions resulted by potassium fertilizer use was a negligible amount in the process of maize production. In addition, soil $\mathrm{N}_{2} \mathrm{O}$ emission gradually increased year by year as well with an increment of $11.48 \mathrm{~kg} \mathrm{CO}_{2}$-eq ha ${ }^{-1}$ year $^{-1}$. The GHGs emissions from the diesel consumption associated with farm machinery operations (e.g., tillage, sowing, and harvest) also increased by $75.7 \%$, ranging from $148.1 \mathrm{~kg} \mathrm{CO}_{2}$-eq ha ${ }^{-1}$ in 2004 to $260.2 \mathrm{~kg} \mathrm{CO}_{2}$-eq ha ${ }^{-1}$ in 2013. Moreover, the film caused to $1.8-4.2 \%$ of total GHGs emissions in maize production. The seed use and artificial labor contributed to $1.2-2.2$ and $2.5-3.7 \%$ of total GHGs emissions, respectively, while pesticide application was less than $0.8 \%$ in the study.

Changes in carbon footprint with different functional units: The yield of maize showed a significant increasing trend over the past decade, ranging from $6.5 \mathrm{t} \mathrm{ha}^{-1}$ to $9.4 \mathrm{t} \mathrm{ha}^{-1}$ with an increment of $0.3 \mathrm{t} \mathrm{ha}^{-1}$ year $^{-1}$ in Shanxi Province $(P=0.0011$, Fig. 1A). The trend of production value for maize was similar to that of the yield, ranging from $¥ 7.0 \times 10^{3} \mathrm{ha}^{-1}$ to $¥ 20.7 \times 10^{3}$ $\mathrm{ha}^{-1}$ with an increment of $¥ 1.6 \times 10^{3} \mathrm{ha}^{-1}$ year $^{-1}(P<0.0001$, Fig. 1B). However, the cost of maize production significantly increased from $¥ 5.4 \times 10^{3} \mathrm{ha}^{-1}$ in 2004 to $¥ 15.6 \times 10^{3} \mathrm{ha}^{-1}$ in 2013 with a quadratic trend $(P<0.0001$, Fig. $1 C)$. The net income of maize production showed an increasing trend on a whole but with large interannual fluctuations (Fig. 1D), ranging from $¥ 1.3 \times 10^{3} \mathrm{ha}^{-1}$ to $¥ 8.5 \times 10^{3} \mathrm{ha}^{-1}$. In addition, there is no significant correlation between GHGs emissions and the yield, the production value, the cost, and the net income (Table 4).

Furthermore, changes in $\mathrm{CF}$ of maize production with different functional units were evaluated, and distinct differences in the $\mathrm{CF}$ among different functional units were

Table 3. Dynamics of greenhouse gases (GHGs) emissions in the process of maize production in Shanxi Province (kg $\mathrm{CO}_{2}-\mathrm{eq} \mathrm{ha} \mathbf{h a}^{-1}$.

\begin{tabular}{|c|c|c|c|c|c|c|c|c|c|c|}
\hline Items & 2004 & 2005 & 2006 & 2007 & 2008 & 2009 & 2010 & 2011 & 2012 & 2013 \\
\hline \multicolumn{11}{|l|}{ Fertilizers } \\
\hline $\mathrm{N}$ fertilizer & 628.1 & 684.1 & 663.7 & 625.0 & 759.0 & 713.2 & 681.4 & 638.2 & 578.8 & 539.0 \\
\hline $\mathrm{P}_{2} \mathrm{O}_{5}$ fertilizer & 724.9 & 906.7 & 1008.2 & 812.2 & 842.9 & 760.3 & 675.3 & 573.8 & 247.9 & 122.8 \\
\hline $\mathrm{K}_{2} \mathrm{O}$ fertilizer & 1.2 & 10.4 & 13.5 & 2.5 & & 0.4 & & & & \\
\hline compound fertilizer & 363.3 & 231.0 & 313.6 & 363.9 & 310.7 & 336.7 & 421.7 & 539.9 & 671.0 & 901.4 \\
\hline Seed & 78.8 & 76.8 & 74.5 & 78.0 & 69.3 & 66.4 & 58.5 & 56.2 & 48.1 & 49.0 \\
\hline Pesticides & 27.4 & 27.4 & 27.4 & 27.4 & 27.4 & 27.4 & 27.4 & 27.4 & 27.4 & 27.4 \\
\hline Labor & 134.4 & 126.8 & 121.3 & 115.8 & 123.2 & 117.3 & 117.5 & 116.4 & 102.8 & 100.2 \\
\hline Agricultural film & 85.2 & 81.8 & 78.4 & 115.9 & 75.0 & 75.0 & 112.5 & 126.1 & 163.6 & 170.4 \\
\hline Irrigation & 328.3 & 428.9 & 465.0 & 521.2 & 636.9 & 705.7 & 530.2 & 579.6 & 960.2 & 644.1 \\
\hline \multicolumn{11}{|l|}{ Machinery operation } \\
\hline Tillage & 62.0 & 62.7 & 61.1 & 69.4 & 72.8 & 72.6 & 71.9 & 76.0 & 93.8 & 108.9 \\
\hline Sowing & 23.9 & 24.2 & 23.6 & 26.8 & 28.1 & 28.0 & 27.7 & 29.4 & 36.2 & 42.1 \\
\hline Harvest & 62.2 & 62.8 & 61.3 & 69.6 & 72.9 & 72.8 & 72.0 & 76.2 & 94.0 & 109.2 \\
\hline Soil $\mathrm{N}_{2} \mathrm{O}$ & 1114.1 & 1127.5 & 1129.3 & 1126.9 & 1218.7 & 1151.3 & 1165.8 & 1173.3 & 1147.0 & 1228.9 \\
\hline Total & 3633.7 & 3850.9 & 4040.8 & 3954.6 & 4236.9 & 4126.9 & 3962.1 & 4012.4 & 4170.8 & 4043.3 \\
\hline
\end{tabular}

The GHGs emissions from agricultural inputs were calculated through multiplying the actual amount of agricultural inputs and relevant emission factors. Soil $\mathrm{N}_{2} \mathrm{O}$ was estimated using the 2006 IPCC Guidelines for National Greenhouse Gas Inventories (IPCC, 2006). 

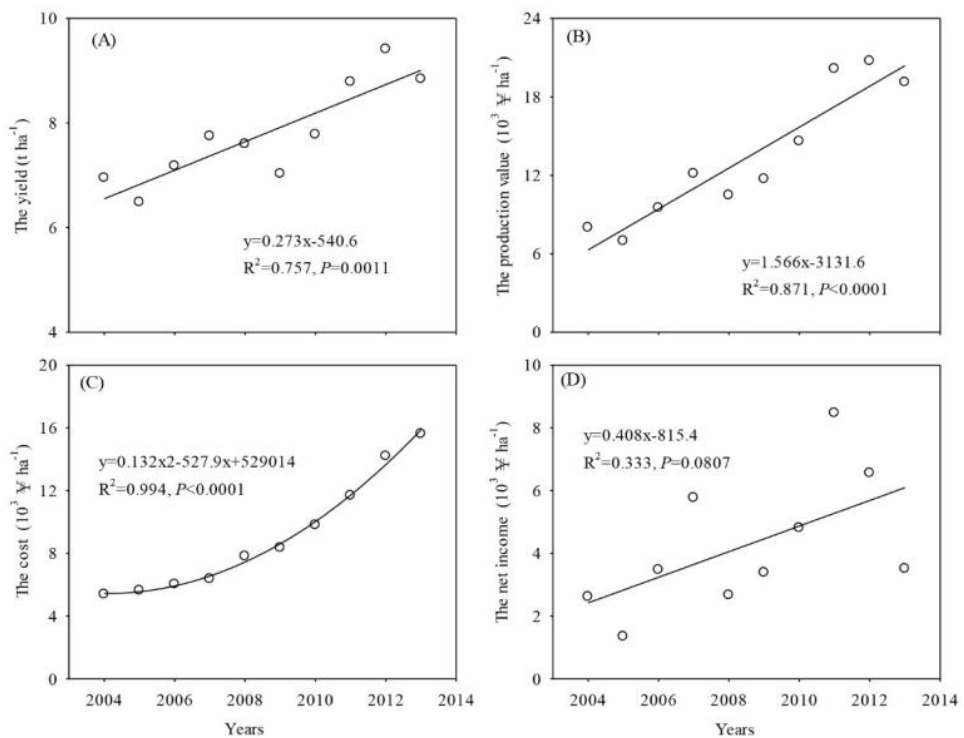

Figure 1. Dynamics of the maize yield (A), production value (B), cost (C), and net income (D).
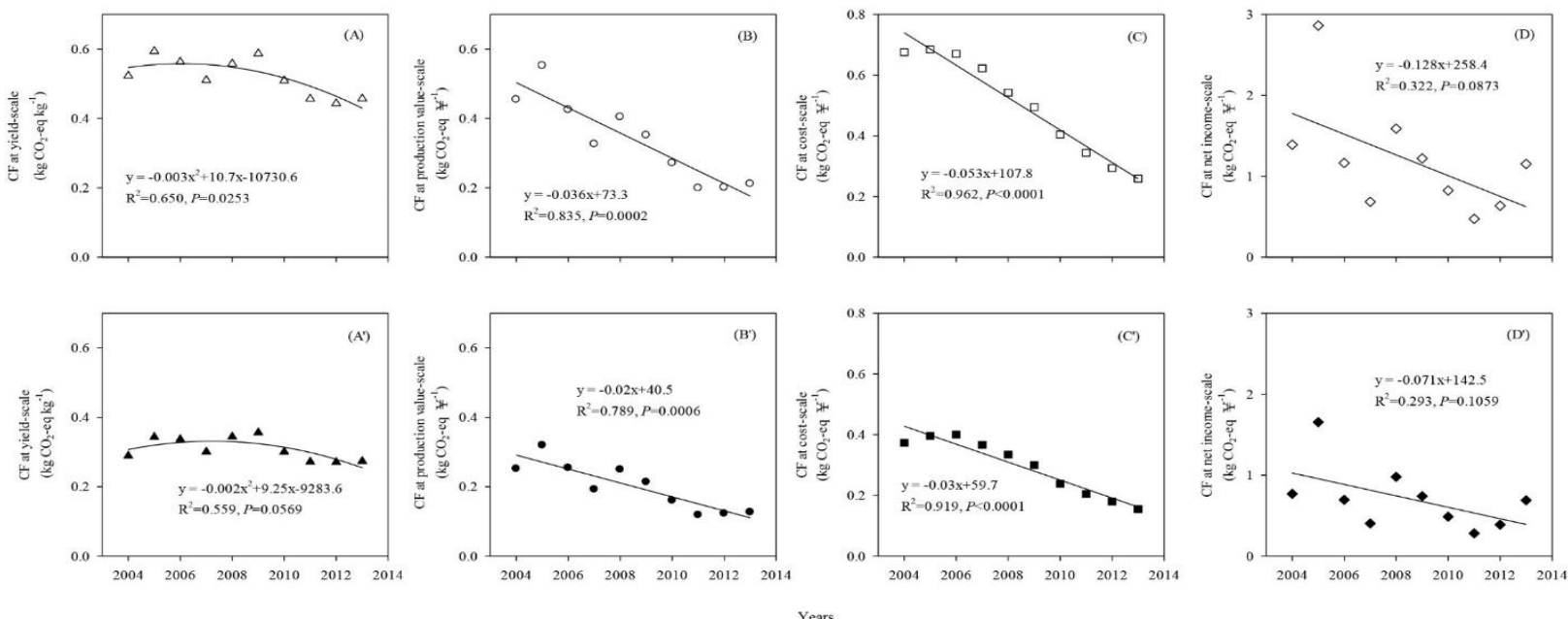

Figure 2. Dynamics of carbon footprint of maize production at yield- (A), production value- (B), cost- (C), net income (D)-scale excluding the change in SOC stock. In addition, $\mathrm{A}^{\prime}, \mathrm{B}^{\prime}, \mathrm{C}^{\prime}$, and $\mathrm{D}^{\prime}$ indicate carbon footprint at yield-, production value-, cost-, net income-scale including the change in SOC stock, respectively

observed (Fig. 2). Regardless of the change in SOC storage, the $\mathrm{CF}$ of maize production showed a decreasing tread for different functional units. Excluding SOC storage, the CF of maize in Shanxi Province ranged from 0.44-0.59 $\mathrm{kg} \mathrm{CO}_{2}$-eq $\mathrm{ha}^{-1}$ at yield-scale (Fig. 2A), $0.20-0.55 \mathrm{~kg} \mathrm{CO}_{2}$-eq $¥^{-1}$ at production value- scale (Fig. 2B), $0.26-0.68 \mathrm{~kg} \mathrm{CO}_{2}$-eq $¥^{-1}$ at cost- scale (Fig. 2C), and $0.47-2.86 \mathrm{~kg} \mathrm{CO}_{2}$-eq $¥^{-1}$ at net income-scale (Fig. 2D), respectively. Including SOC storage, the $\mathrm{CF}$ of maize production with different functional units decreased compared to those excluding SOC storage (Fig. 2A', $\left.\mathrm{B}^{\prime}, \mathrm{C}^{\prime}, \mathrm{D}^{\prime}\right)$. The $\mathrm{CF}$ of maize decreased by $38.3-44.7 \%$ at both yield-, production value-, cost-, and net income-scales.
Table 4. The relationship between greenhouse gases emissions and the yield, production value, cost, and net income for the maize production.

\begin{tabular}{lcccc}
\hline & Yield & $\begin{array}{c}\text { Production } \\
\text { value }\end{array}$ & Cost & Net income \\
\hline GHGs emission & $0.458^{\mathrm{ns}}$ & $0.443^{\mathrm{ns}}$ & $0.466^{\mathrm{ns}}$ & $0.254^{\mathrm{ns}}$ \\
\hline
\end{tabular}

${ }^{n s}$ indicates that there is no significant correlation.

\section{DISCUSSION}

Influencing factors of GHGs emissions in maize production: In the study, the GHGs emissions from maize production 
increased year by year, mainly due to chemical fertilizers use in Shanxi Province. Rapid increase in chemical fertilizers use, especially nitrogen fertilizer and compound fertilizer, resulted in a mass of soil $\mathrm{N}_{2} \mathrm{O}$ emission and hidden GHGs emissions. Meanwhile, most of fertilizers lost into the surrounding environment by volatilization and leaching due to low fertilizers use efficiency at the growth stage of maize, resulted in a series of environmental problems (Galloway et al., 2008). Therefore, the reduction of fertilizers application amount and improvement of fertilizers use efficiency could be important ways to mitigate GHGs emissions from maize production. According to the Zero Increase in Chemical Fertilizers Use Action by 2020 program (MAPRC, 2015), some technical measures were popularizing and implementing to reduce fertilizers use amount and improve fertilizers use efficiency, including the promotion of precision fertilization, the structure adjustment of chemical fertilizer use, the improvement of fertilization method, and the replacement of chemical fertilizers by organic fertilizer. For example, utilizing the "Nation Fertilization According to Soil Test Result" program improved fertilizer use efficiency of maize to 32,25 and $43 \%$ for nitrogen fertilizer, phosphate fertilizer and potassium fertilizer in China since 2005, respectively (MAPRC, 2013). Then, GHGs emissions could be reduced by the implementation of above programs due to the reduction of chemical fertilizers use amount.

In addition, adoption of no-tillage practice could effectively reduce hidden GHGs emissions caused by farm machinery operations and soil $\mathrm{N}_{2} \mathrm{O}$ emission in the process of maize cropping (Ussiri et al., 2009). Adoption of water-saving technology could be also a possible solution to reduce GHGs emissions from irrigation. In this study, pesticides were only a small part of total GHGs emissions in maize production. However, farmers generally used excessive pesticides to control pests and weeds, which could result in increased cost of maize production (NDRCPRC, 2005-2014). Meanwhile, excessive use of pesticides could retain in agricultural products and the surrounding farmland, affecting the quality of maize and posing a threat to environment (MAPRC, 2015). Therefore, the use of pesticides should be controlled in the process of maize production. Currently, it is a controversial viewpoint on whether to take the energy consumption of laborer into consideration or not in the CF calculation. West and Marland (2002) considered that the energy consumption of human labor should not be included, because humans respire $\mathrm{CO}_{2}$ regardless of whether human laborers are working or not. However, Liu et al. (2013) deemed that the energy consumption associated with human labor should not be ignored, because human labor was one of the important parts of agricultural production in developing countries. Li et al. (2009) calculated also the energy consumption of human labor when calculating GHGs emissions from agriculture production.

Carbon footprint of maize and influence factor: At present, numerous studies reported the average $\mathrm{CF}$ of maize in China, with $0.230 \mathrm{~kg} \mathrm{CO}_{2}$-eq kg-1 (Liu et al., 2015), $0.44 \mathrm{~kg} \mathrm{CO}_{2}$-eq $\mathrm{kg}^{-1}$ (Cheng et al., 2015), and $0.33 \mathrm{~kg} \mathrm{CO}_{2}$-eq kg-1 (Yan et al., 2015). In our study, the $\mathrm{CF}$ of maize at yield-scale ranged from 0.44 to $0.59 \mathrm{~kg} \mathrm{CO}_{2}$-eq $\mathrm{kg}^{-1}$ for excluding SOC storage in Shanxi Province, which was higher than those of abovementioned average value. Taking SOC storage into consideration, the CF decreased to $0.27-0.36 \mathrm{~kg} \mathrm{CO}_{2}$-eq kg-1 , similar with the result reported by Yan et al. (2015). This may be attributed to differences in the calculation method, the regional scale, and emission factors of agricultural inputs. In the study, the CF was calculated by using life cycle assessment with the GHGs emissions inventory for maize production in detail, which could result in larger GHGs emissions than other studies. Localized emission factors were used to calculate GHGs emissions in current study, which were higher than abroad generally leading to greater CF of maize than that in other studies. In addition, the difference in maize yield could cause the gap of CF among different studies due to the discrepancy of climate condition, cropping system, and agricultural technology.

Taking into account SOC storage, the CF of agricultural product sharply decreased after the adoption of farming management practices associated with SOC sequestration and GHGs emissions reduction (Gan et al., 2012; Xue et al., 2014). In this study, the $\mathrm{CF}$ of maize with different functional units decreased after taking SOC storage into consideration. At present, the change in SOC storage was estimated at the rate of $1624.3 \mathrm{~kg} \mathrm{CO} 2$-eq ha ${ }^{-1}$ year $^{-1}$ in cropland of Shanxi Province (Lu et al., 2009), which could affect strongly the CF after taking SOC storage into consideration. However, the change in SOC storage in maize field is not clear in Shanxi Province, it is necessary to assess it in the future.

Currently, the CF of agricultural products was calculated at area- and yield-scale in most studies. The cost and income of agricultural production strongly influenced farmer planting intention and GHGs emissions in the condition of market economy, however, few studies assessed the CF of agricultural product at economy-scale. It is necessary to quantify the relationship between economic profit and GHGs emissions. In our study, the CF of maize production was evaluated based on different functional units (at yield-, production value-, cost-, net income-scale) in Shanxi Province. The gap of the $\mathrm{CF}$ under functional units was observed, especially the $\mathrm{CF}$ at net income-scale with great fluctuation was larger than those at other functional units in the study. This may be due to larger fluctuation on net income for maize production among years. In addition, there was an increasing trend for the yield, production value, the cost, and the net income with GHGs emissions for maize production in Shanxi Province. However, decreasing trends were observed for all CFs of maize with different functional units. Therefore, the decrease of the CF of maize under different functional units was not meant to mitigate climate change. 
A limitation of the current study: In the study, soil $\mathrm{N}_{2} \mathrm{O}$ emission was estimated using the method from the 2006 IPCC Guidelines for National Greenhouse Gas Inventories (IPCC, 2006) in Shanxi Province, which could be different with actual $\mathrm{N}_{2} \mathrm{O}$ emission from the maize field. In addition, there could be difference in soil $\mathrm{N}_{2} \mathrm{O}$ emission among different regions due to the divergence of climatic condition, soil texture, and farm management. In addition, differences in soil water content and soil nitrogen cycle could be presented between film mulching in the north region and non-mulching in the south region of Shanxi Province, which could affect soil nitrification and denitrification resulting in the difference in soil $\mathrm{N}_{2} \mathrm{O}$ emission (Kool et al., 2011). In addition, the static closed chamber technology is a comment method to measure soil $\mathrm{N}_{2} \mathrm{O}$ flux (Hénault et al., 2012; Berger et al., 2013), and more work should be done by the technology to accurately evaluate soil $\mathrm{N}_{2} \mathrm{O}$ emission and the $\mathrm{CF}$ of crop for future research. Furthermore, lift cycle assessment was generally used to evaluate the environment impact of a product from the cradle to the grave, a detailed inventory dataset within the system boundary was needed to calculate the CF of agricultural product. However, it is more difficult to collect all relevant datasets for the CF calculation at macro-scale than at micro-scale. Therefore, some missing datasets were obtained by other methods, such as soil $\mathrm{N}_{2} \mathrm{O}$ emission, the change in SOC stock. To improve the quality of data would assess accurately the $\mathrm{CF}$ of a product at a regional scale.

Conclusion: From 2004 to 2013, the GHGs emissions from maize production showed an increasing trend in Shanxi Province. The application of chemical fertilizers, soil $\mathrm{N}_{2} \mathrm{O}$ and irrigation contributed $>85 \%$ of total GHGs emissions in the process of maize production. The yield, production value and cost of maize production significantly increased in Shanxi Province year by year, however, the net income showed a large fluctuation among years. In addition, the $\mathrm{CF}$ of maize with different functional units showed a decreasing trend, which was reduced by $38.3-44.7 \%$ after taking change in SOC storage into account. Overall, reducing fertilizer use, strengthening mechanical integration and improving SOC sequestration could be some potential solutions to cut down the CF of maize production in Shanxi Province.

Acknowledgements: This research was supported by Project Funded by China Postdoctoral Science Foundation (2015M581322, 2017T100169), Special Fund for Agroscientific Research in the Public Interest in China (201303104), and the project of Technology System in Modern Wheat Industry, Chinese Ministry of Agriculture (CARS-03-01-24).

\section{REFERENCES}

Berger, S., Y. Kim, J. Kettering and G. Gebauer. 2013. Plastic mulching in agriculture-Friend or foe of $\mathrm{N}_{2} \mathrm{O}$ emissions. Agric. Ecosyst. Environ. 167:43-51.

Cheng, K., M. Yan, D. Nayak, G.X. Pan, P. Smith, J.F. Zheng and J.W. Zheng. 2015. Carbon footprint of crop production in China: an analysis of national statistics data. J. Agric. Sci. 153:422-431.

Cui, X.C., A.N. Li, G.Z. Wang and D.C. Wang. 2011. Research on machinery cost of grain-production in China-Based on a nationwide questionnaire survey. J. Agr. Mech. Res. 2:15-18.

Dubey, A. and R. Lal. 2009. Carbon footprint and sustainability of agricultural production systems in Punjab, India, and Ohio, USA. J. Crop Impr. 23:332-350.

Finkbeiner, M. 2009. Carbon footprinting-opportunities and threats. Int. J. Life Cycle Assess. 14:91-94.

Galloway, J.N., A.R. Townsend, J.W. Erisman, M. Bekunda, Z. Cai, J.R. Freney, L.A. Martinelli, S.P. Seitzinger and M.A. Sutton. 2008. Transformation of the nitrogencycle: recent trends, questions, and potential solutions. Science. 320:889-892.

Gan, Y.T., C. Liang, C.A. Campbell, R.P. Zentner, R.L. Lemke, H. Wang and C. Yang. 2012. Carbon footprint of spring wheat in response to fallow frequency and soil carbon changes over 25 years on the semiarid Canadian prairie. Eur. J. Agron. 43:175-184.

Guo, J. and C. Zhou. 2007. Greenhouse gas emissions and mitigation measures in Chinese agroecosystems. Agr. Forest Meteorol. 142:270-277.

Hénault, C., A. Grossel, B. Mary, M. Roussel and J. Léonard. 2012. Nitrous oxide emission by agricultural soils: a review of spatial and temporal variability for mitigation. Pedosphere 22:426-433.

IPCC (Intergovernmental Panel on Climate Change). 2006. 2006 IPCC Guidelines for National Greenhouse Gas Inventories. Institute for Global Environmental Strategies, Hayama, Kanagawa, Japan.

ISO (International Organization for Standardization). 2013. TS ISO 14067: Greenhouse Gases-Carbon Footprint of Products-Requirements and Guidelines for Quantification and Communication. International Organization for Standardization, Geneva, Switzerland.

Kool, D.M., J. Dolfing, N. Wrage and J.W. Van Groenigen. 2011. Nitrifier denitrification as a distinct and significant source of nitrous oxide from soil. Soil Biol. Biochem. 43:174-178.

Li, J.J., G.X. Pan, L.Q. Li and X.H. Zhang. 2009. Estimation of net carbon balance and benefit of rice-rice cropping farm of a red earth paddy under long term fertilization experiment from Jiangxi, China. J. Agro-Environ. Sci. 28:2520-2525.

Liu, Q.Q., J. Wang, R.R. Chen, W.Z. Liu and U.M. Sainju. 2015. Short-term response of soil $\mathrm{CH}_{4}$ flux to simulated precipitation in a winter wheat field on the Loess Plateau, Northwest China. Chin. J. Appl. Ecol. 26:140-146. 
Liu, X., W. Xu, Z. Li, Q. Chu, X. Yang and F. Chen. 2013. The missteps, improvement and application of carbon footprint methodology in farmland ecosystems with the case study of analyzing the carbon efficiency of China's intensive farming. Chin. J. Agr. Res. Reg. Plan. 34:1-11.

Lu, F., X. Wang, B. Han, Z. Ouyang, X. Duan, H. Zheng and H. Miao. 2009. Soil carbon sequestrations by nitrogen fertilizer application, straw return and no-tillage in China's cropland. Glob. Change Biol. 15:281-305.

MAPRC (Ministry of Agriculture of the People's Republic of China). 2013. Promoting the steady improvement of fertilizers use efficiency, fertilizers use efficiency upto 33\% by scientific fertilization in China. Available online with updates

at http://www.moa.gov.cn/zwllm/zwdt/201310/t20131010 3625203.htm.

MAPRC (Ministry of Agriculture of the People's Republic of China). 2015. The action program of zero growth of chemical fertilizers use amount by 2020 and the action program of zero growth of pesticides use amount by 2020 . Available online with updates at http://www.moa.gov.cn/zwllm/tzgg/tz/201503/t2015031 8 4444765.htm.

NBSPRC (National Bureau of Statistics of the People's Republic of China). 2016. China Statistical Yearbook 2016. China Statistics Press, Beijing.
NBSPRC (National Bureau of Statistics of the People's Republic of China). 2005-2014. China Rural Statistical Yearbook. China Statistics Press, Beijing.

NDRCPRC (National Development and Reform Commission of the People's Republic of China). 2005-2014. The National Cost-Benefit Survey for Agricultural Products. China Statistics Press, Beijing.

Pathak, H., N. Jain, A. Bhatia, J. Patel and P.K. Aggarwal. 2010. Carbon footprints of Indian food items. Agric. Ecosyst. Environ. 139:66-73.

Ussiri, D.A.N., R. Lal and M.K. Jarecki. 2009. Nitrous oxide and methane emissions from long-term tillage under a continuous corn cropping system in Ohio. Soil Tillage. Res. 104:247-255.

West, T.O. and G. Marland. 2002. Net carbon flux from agricultural ecosystems: methodology for full carbon cycle analyses. Environ. Pollut. 116:439-444.

Xue, J.F., S.L. Liu, Z.D. Chen, F. Chen, R. Lal, H.M. Tang and H.L. Zhang. 2014. Assessment of carbon sustainability under different tillage systems in a double rice cropping system in Southern China. Int. J. Life Cycle Assess. 19:1581-1592.

Yan, M., K. Cheng, T. Luo, Y. Yan, G. Pan and R.M. Rees. 2015. Carbon footprint of grain crop production in China based on farm survey data. J. Clean. Prod. 104:130-138. 